\title{
An Efficient One-Pot Synthesis of Dihydropyrimidinones Under Solvent-Free Conditions
}

\author{
FARHAD HATAMJAFARI and FATEMEH GERMANI NEZHAD* \\ Department of Chemistry, Faculty of Science, \\ Islamic Azad University-Tonekabon Branch, Tonekabon, Iran. \\ *Corresponding author E-mail: fatemehgermaninezhad@yahoo.com
}

http://dx.doi.org/10.13005/ojc/300148

(Received: January 01, 2014; Accepted: February 06, 2014)

\begin{abstract}
An efficient method for one-pot synthesis of 3,4-Dihydropyrimidin-2-(1H) -one derivatives the Biginelli condensation reaction of aromaticaldehydes, $\beta$-ketoesters and urea under solvent-free conditions was described.
\end{abstract}

Key words: Biginelli Reaction, Dihydropyrimidinones, One-pot, Solvent-Free .

\section{INTRODUCTION}

Multicomponent reactions play an important role in pharmaceutical industries. Pharmacies are trying to develop green chemistry reactions. Solventfree synthesis of complex organic structures as drugs is the dream of every pharmacy. Multicomponents reaction as a powerful tool for the rapid introduction of molecular diversity is evident and developed for the generation of heterocycles receives growing interest ${ }^{1-3}$.

Dihydropyrimidinones (DHPMs) as well as heterocyclic compound in the natural and synthetic organic chemistry due to their wide range of biological and therapeutic properties such as anti-viral anti-inflammatory, anti-tumor, and antibacterial activities ${ }^{4-5}$. Biginelli reaction is one of the most important multi-component reactions for the synthesis of dihydropyrimidinones. 3,4dihydropyrimidin-2-(1H) ones (DHPMs) reported that the activity of many drugs as anti-viral, anti-bacterial and anti-hypertensive effects as calcium channel modulators and as Multi-drug resistance reversal. Biological activity of some alkaloids isolated recently to 3,4 dihydropyrimidin-2-(1H) -ones moiety. It was first synthesized by Biginelli in 1893. DHPMs as a pot condensation of an aldehyde, diketone and urea under acidic conditions. This method undergoes from low yields especially in the cases of some substituted aldehydes. To increase the efficiency of the reaction, Biginelli, various catalysts have been used ${ }^{6-8}$. .

However, these reactions often require harsh conditions and long reaction time and low efficiency can. Aliphatic and aromatic aldehydes, especially when used to replace for synthesis Dihydropyrimidinones (DHPMs). 
Although numerous methods are capable of affecting these synthesis has been previously reported $^{9-18}$. Previously, we have synthesized a number of heterocyclic compounds ${ }^{19-30}$. Herein we report some of DHPMs at one pot reaction, environmentally friendly with high yields and easy separation (Scheme 1).

\section{EXPERIMENTAL}

General Procedure for the Preparation of ethyl 1,2,3,4-tetrahydro-6-methyl-2-oxo-4phenylpyrimidine-5-carboxylate

A mixture of ethyl acetoacetate $(1 \mathrm{mmol})$, benzaldehyde $(1 \mathrm{mmol})$ and urea $(1.4 \mathrm{mmol})$ was heateded for $90 \mathrm{~min}$. All reactions were monitored by TLC and the obtained solid was filtered, the solid was washed with water and recrystallized using absolute ethanol.<smiles>[R][X]C(C)C(=O)C1=C(C)NC(=O)NC1c1ccccc1</smiles>

Scheme 1:

yield: $\left(\Phi \%, m 201-204^{\circ} \mathrm{C}\right.$

$F-R(K B r d i s c): 3444,3220,2910,1715,1640 ; n^{-1}$.

\section{RESULTS AND DISCUSSION}

Herein, we reported an efficient, high yield, environmentally friendly, easy separation and simple route for the synthesis of DHPMs under solvent-free conditions.

\section{ACKNOWLEDGEMENTS}

We gratefully acknowledge the financial support from the Research Council of Tonekabon Branch Islamic Azad University.

\section{REFERENCES}

1. Ma N., Jiang B., Zhang G., Tu S. J., Wever W and Li G., Green Chemistry, 12: 1357 (2010).

2. Yue T., Wang M. X., Wang D.X., Masson G and Zhu J., J. O. Chem., 74: 8396 (2009).

3. Trofimov B. A., Andriyankova L. V., Belyaeva K. V et al., Eur. J. O. Chem., 9: 1772 (2010).

4. Balme G., Bossharth E and Monteiro N., Eur. J. Org.Chem., 21: 4101 (2003).

5. $\quad$ Kappe, C.O. Tetrahedron, 49: 6937 (1993).

6. Kappe, C.O. Acc. Chem. Res., 33: 879 (2000).

7. Snider, B.B.; Chen, J.; Patil, A.D.; Freyer, A. Tetrahedron Lett., 37: 6977 (1996).
8. Biginelli, P. Gazz. Chim. Ital., 23: 360 (1893).

9. Banik, B.K.; Reddy, A.T.; Datta A.; Mukhopadhyay C. Tetrahedron Lett., 48: 7392 (2007).

10. Li, J.T.; Han, J.F.; Yang, J.H.; Li, T.S. Ultrason. Sonochem., 10: 119 (2003).

11. Peng, J.J.; Deng, Y.Q. Tetrahedron Lett., 42: 5917 (2001).

12. Ma, Y.; Qian, C.; Wang, L.; Yang, M. J. Org. Chem., 65: 3864 (2000).

13. Ahmed, N.; Lier, J.E.V. Tetrahedron Lett., 48: 5407 (2007).

14. Adib, M.; Ghanbary, K.; Mostofi, M.; Ganjali, 
M.R. Molecules, 11: 649 (2006).

15. Karade, H.N.; Sathe, M.; Kaushik, M.P. Molecules, 12:1341 (2007).

16. Cheng, J.; Qi, D.Y. Chin. Chem. Lett., 18: 647 (2007).

17. Liu, C.J.; Wang, J.D.; Li, Y.P. J. Mol. Catal. $A$ Chem., 258: 367 (2006).

18. Zhang, X.L.; Li, Y.P.; Liu, C.J.; Wang, J.D. J. Mol. Catal. A Chem., 253: 207 (2006).

19. Azizian J., Hatamjafari F., Karimi A. R. and Shaabanzadeh M., Synthesis, 5: 765 (2006).

20. Azizian J., Shaabanzadeh M., Hatamjafari F. and Mohammadizadeh M.R., Arkivoc, (xi): 47 (2006).

21. Hatamjafari F., Synthetic Communications, ý 36: 3563 (2006).

22. Azizian J., Hatamjafari F. and Karimi A. R.,
Journal of Heterocyclic Chemistry, 43: 1349 (2006).

23. Hatamjafari F and Montazeri N., Turkish Journal of Chemistryý, 33: 797 (2009).

24. Bidram A., Hatamjafari $F$ and Doryeh A., Orient. J. Chem., 29: 123 (2013).

25. Hatamjafari F., Orient. J. Chem., 28: 141 (2012).

26. Hatamjafari F., Orient. J. Chem., 29: 93(2013).

27. Hatamjafari F and Alijanichakoli F., Orient. J.Chem., 29: 145(2013).

28. Hatamjafari $F$ and Hosseinian A., Orient. J.Chem., 29: 109(2013).

29. Hatamjafari $\mathrm{F}$ and Keyhani A., Orient. J.Chem., 29: 783 (2013).

30. Hatamjafari $\mathrm{F}$ and Khojastehkouhi H., Orient. J. Chem., 30: (2014 in press). 